\title{
Behavior of Aluminum Compounds in Soft-Water Lakes Subjected to Experimental Reclamation with Polyaluminum Chloride
}

\author{
Michal Lopata (D) - Renata Augustyniak (D) • Jolanta Grochowska (D) • \\ Katarzyna Parszuto (D) - Renata Tandyrak (D) - Grzegorz Wiśniewski
}

Received: 31 May 2019 / Accepted: 10 June 2020/Published online: 7 July 2020

(C) The Author(s) 2020

\begin{abstract}
The research presented in this work concerns the potential aluminum load of soft-water lake ecosystems as a result of performing chemical reclamation works. On a semitechnical scale, different doses of PAC-type aluminum coagulant (polyaluminum chloride) were tested. The required doses of coagulant (on average, $11 \mathrm{mg} \mathrm{Al} / \mathrm{L}$ ) were determined based on the amount of phosphorus that is bioavailable in the lake ecosystem. The research covered the lake water, nearbottom and interstitial water, and bottom sediments of five lakes with low alkalinity (0.4-2.5 meq/L) and low calcium contents $(5-35 \mathrm{mg} \mathrm{Ca} / \mathrm{L})$. The experiments were conducted in situ for 2 years using mesocosms with a volume of approximately $20 \mathrm{~m}^{3}$. The effectiveness of the flocculation and sedimentation processes of coagulant flocs was closely related to changes in water $\mathrm{pH}$ caused by acidic coagulant application, and the corresponding transformation level ranged from 39.8 to $99.8 \%$. In the waters of these lakes, where the alkalinity did not reach $1 \mathrm{meq} / \mathrm{L}$, the coagulant used in doses adequate for intensive full-scale projects caused high water pollution with dissolved aluminum fractions (from $0.05 \pm 0.01$ to $4.67 \pm 1.32 \mathrm{mg} \mathrm{Al} / \mathrm{L}$ ). In all lakes, the penetration of dissolved aluminum into the interstitial water of the bottom sediment was limited to the first
\end{abstract}

M. Łopata $(\bowtie) \cdot$ R. Augustyniak · J. Grochowska •

$\mathrm{K}$. Parszuto $\cdot \mathrm{R}$. Tandyrak $\cdot \mathrm{G}$. Wiśniewski

Department of Water Protection Engineering and Environmental Microbiology, Faculty of Geoengineering, University of Warmia and Mazury in Olsztyn, 1 Prawocheńskiego St., Olsztyn, Poland e-mail: michal.lopata@uwm.edu.pl 5-cm layer. After the application of coagulant, the aluminum content in the bottom sediments significantly increased in proportion to the amount of the PAC used (by $12-96 \%$ in terms of a 5 -cm surface layer of sediment). Within 2 years of the research, solid fractions (flocks) of the coagulant moved to a depth of 5-10 cm below the bottom level. Due to high release rates of aluminum from the applied aluminum treatments, modifications to the treatment protocols are needed in softwater lakes.

Keywords Lake restoration - Alkalinity · Mesocosms · Coagulation · Aluminum

\section{Introduction}

The problem of surface water eutrophication is becoming an increasingly serious threat to the conservation of natural resources, the protection of biodiversity, and the economic use of water. The poor ecological status of lakes has led to losses for the tourism industry (Lopata et al. 2016a), and it is particularly severe in developing societies. Water quality deterioration also causes the unfavorable reconstruction of ichthyofauna caused by the retreat of environmentally valuable and economically desirable species. Mass algal blooms are a real problem in potable water reservoirs and in the case of industrial abstraction.

Various protective measures have been taken in different catchments to counteract the effects of eutrophication (Lossow 1998; Jeppesen et al. 2007). The aim of 
such measures is to stop the inflow of contaminants to lakes. Considerable progress has been observed in recent decades in the water and sewage industry in terms of reducing nutrient-rich effluents from point sources, and these efforts can significantly improve the environmental conditions in water ecosystems exposed to such pressures (Jeppesen et al. 2005). However, it is much more difficult to control inflows from nonpoint sources related to agricultural use in a lake catchment (Code of Good Agricultural Practices 2004; Gawrońska and Lossow 2008; Davis and David 2018). Restrictive fertilization management is often faced by opposition from farmers. Even if a reduction in fertilizer levels is achieved, the effectiveness of these practices is rarely sufficient for eliminating the external load to a level that is acceptable for lake ecosystems; additionally, improvements in water quality are generally slow (Kajak 2001). Therefore, to increase the efficiency of lake restoration, various treatments have been applied, including technical measures (hypolimnetic withdrawal, artificial aeration, dredging, flushing, and capping - Olszewski 1961; Dunalska et al. 2007; Siwek et al. 2018; Lopata et al. 2020), chemical measures (phosphorus inactivation, bottom sediment biochemical oxidation, and the use of anti-cyanobacteria agents-Ripl 1986; Wiśniewski et al. 2010; Grochowska et al. 2019; Chróst 2017), and biological measures (ichthyofauna structure steering, bioseston removal, macrophyte planting, biofiltration mollusk introduction, and the promotion of beneficial microorganisms-Shapiro and Wright 1984; Gołdyn 2000; Jeppesen et al. 2012).

Numerous case studies have shown that lake reclamation is associated with high uncertainty of success due to the large number of interactions involved in the biological balance of a lake ecosystem. The key to achieving the expected results is to recognize the causes of lake degradation and select the most appropriate method (or set of methods) based on the prevailing hydrological, morphometric, physicochemical, and biological conditions of a given waterbody (Lopata et al. 2020). Among the reclamation techniques used, phosphorus inactivation is one of the most effective. Phosphorus is an important nutrient, and it is susceptible to precipitation in the water column with the use of reagents. Hence, the use of coagulants for the purification of lakes is a universal and generally effective approach.

The most commonly used reagents for phosphorus inactivation are based on iron, aluminum, and calcium salts. The first two elements are usually used in the form of strong acidic chloride or sulfate solutions (Klapper 1991; Cooke et al. 2005). Hence, the corresponding doses into natural water are limited by the ability to neutralize the acidifying factor. Due to the potential toxic effects of coagulants (aluminum-based coagulants in particular), it is assumed that soft-water lakes should not be restored by these methods. However, with the introduction of increasingly better coagulants and the increasing diversity of buffer capacities in various soft-water lakes, it can be assumed that it is possible to use environmentally safe phosphorus inactivation methods in some soft-water lakes. To date, no extensive research has been conducted regarding the potential directions of aluminum transformation in the environment for soft-water lakes. Thus, the objective of this study was to assess the effects of different coagulant doses on aluminum behavior in natural, poorly buffered lake ecosystems.

In our research, we tested several scenarios of the water ecosystem response to the reclamation treatment based on the recognition of aluminum changes in the water and bottom sediment inside experimental mesocosms.

\section{Material and Methods}

\subsection{Experimental Reservoirs}

The research project involved five lakes: Zbiornik Zachodni (ZZ, 4.0 ha/max depth $7.0 \mathrm{~m}$ ), Kluka Mała (KM, 3.4 ha/max depth $4.1 \mathrm{~m}$ ), Kluka Duża (KD, $11.3 \mathrm{ha} / \mathrm{max}$ depth $5.7 \mathrm{~m}$ ), Podkówka (POD, $6.9 \mathrm{ha} /$ max depth $6.0 \mathrm{~m}$ ), and Redykajny (RED, 29.9 ha/max depth $20.6 \mathrm{~m}$ ), located in the Olsztyn Lake District (Warmian-Masurian Voivodeship, Poland). All lakes are dimictic, with two periods of stratification (summer and winter) and spring and autumn mixing. Additionally, these lakes are characterized by a similar nutrient level (phosphorus average of $0.07-0.14 \mathrm{mg} / \mathrm{L}$ and nitrogen average of $1.2-1.8 \mathrm{mg} / \mathrm{L}$ ) corresponding to a eutrophic status based on the commonly accepted OECD classification (OECD 1982). The watersheds of all water bodies have similar moderate levels of urban and agricultural development (mosaic of forests, arable fields, and dispersed buildings). Due to the excessive multiannual inflow of nutrients from spatial sources, in every lake, the production of autochthonous organic matter has increased, the bottom waters undergo oxygen depletion, and the process of internal enrichment with 
phosphorus has begun. Therefore, these lakes could benefit from reclamation activities.

All the selected reservoirs have soft water (Lopata et al. 2016b). However, the features that distinguish the different lakes are the concentrations of buffer substances (alkalinity, meq/L: ZZ $0.45 \pm 0.06, \mathrm{KD} 0.48 \pm$ $0.05, \mathrm{KM} 0.69 \pm 0.18$, POD $1.73 \pm 0.10$, and RED 2.48 \pm 0.22 ), which are associated with different calcium levels $(4.11 \pm 0.96,5.44 \pm 1.78,6.34 \pm 0.94,23.21 \pm$ 2.46 , and $38.02 \pm 3.66 \mathrm{mg} \mathrm{Ca} / \mathrm{L}$, respectively; data from the 2013 growing season; $n=5$ ).

\subsection{The Study Design}

Because the selected lakes had different buffer capacities but similar levels of water quality degradation, they were acceptable for studying the various responses of lake ecosystems to aluminum. To optimize the application value of these results, it was assumed that the tested coagulant doses were designed according to the guidelines used in full-scale lake reclamation projects involving phosphorus inactivation. The research was conducted in a 2-year cycle.

In each lake, there were four experimental mesocosms in which the behavior of three doses of aluminum compounds was investigated, and the results were compared to the results from a control reservoir. The experimental mesocosms were placed in groups in the sublittoral zone on a homogeneous, flat area of the bottom. The construction of the mesocosms made it possible to enclose approximately $20 \mathrm{~m}^{3}$ of water inside the system and allowed the free exchange of matter and energy between the water and bottom sediments. The sidewalls of the mesocosms were made of smooth plastic with high transparency and low susceptibility to fouling with biofilms to avoid disturbing the natural photosynthesis process. The upper edges of the structure were extended approximately $0.3 \mathrm{~m}$ above the water level to prevent inflow from wave action.

To determine the required dose of coagulant, the Rydin and Welch guidelines (1998) were used with a slight modification by the authors based on the application experience of the scientific team from the Department of Water Protection Engineering at the University of Warmia and Mazury in Olsztyn. The procedure for calculating the theoretical dose of prepared aluminum considered the contents of the bioavailable forms of phosphorus in lake water, interstitial water and bottom sediments. Because the trophic levels in the lakes were similar, the individual doses for the lakes studied were similar (in total, approximately $11 \mathrm{~g} \mathrm{Al} / \mathrm{m}^{3}$ for lake water, which corresponded to 46 $\pm 4 \mu \mathrm{L} / \mathrm{L}$ of the technical preparation per the studied water volume in each study year).

A popular PAC (polyaluminum chloride) preparation was used to inactivate phosphorus. The basic characteristics of the coagulant are included in Table 1.

In the first year of research, in spring, a theoretical dose of coagulant was introduced into three mesocosms in amounts of $25 \%, 50 \%$, and $100 \%$. In the second year of the study, the dosing was repeated using the same amounts at the same time. Finally, this experimental method made it possible to observe the potential environmental effects of half-size (mesocosms " $0.5 \times$ dose"), total (mesocosms " $1.0 \times$ dose") and double (mesocosms " $2.0 \times$ dose") theoretical aluminum doses at the project scale.

The research covered the lake water inside the mesocosms, the near-bottom waters $(\mathrm{N}-\mathrm{B}, 0-10 \mathrm{~cm}$ above the bottom) and the bottom sediments (where solids and interstitial water were analyzed separately to a depth of $20 \mathrm{~cm}$ below the bottom; the sediments were divided into 4 successive layers of lake deposits with a unitary thickness of $5 \mathrm{~cm}$ ). The scope of the research

Table 1 Main technical features and environmental threats of the tested aluminum coagulant (Brenntag 2015)

\begin{tabular}{|c|c|c|}
\hline Parameter & \multicolumn{2}{|l|}{ Description } \\
\hline Chemical characteristics & \multicolumn{2}{|c|}{ Polyaluminum chloride } \\
\hline Form & \multicolumn{2}{|c|}{$\begin{array}{l}\text { A light-yellow aqueous } \\
\text { solution } 30-40 \%\end{array}$} \\
\hline Technical features & Unit & Value \\
\hline Density at $20^{\circ} \mathrm{C}$ & $\mathrm{kg} / \mathrm{m}^{3}$ & $1350-1370$ \\
\hline $\mathrm{Al}$ content & $\%$ & $9 \pm 0.4$ \\
\hline Reaction & $\mathrm{pH}$ & 1.0 \\
\hline Toxicity for hydrobionts & Unit & Value \\
\hline $\begin{array}{l}\text { LC50 for fish (Danio rerio, according } \\
\text { to the OECD Test Guideline 203) }\end{array}$ & $\mathrm{mg} / \mathrm{L} / 96 \mathrm{~h}$ & $>1000$ \\
\hline $\begin{array}{l}\text { NOEC for fish (Danio rerio, } \\
\text { according to the OECD Test } \\
\text { Guideline 203) }\end{array}$ & $\mathrm{mg} / \mathrm{L}$ & $>1000$ \\
\hline $\begin{array}{l}\text { EC50 for invertebrates (Daphnia } \\
\text { magna, according to the OECD } \\
\text { Test Guideline 202) }\end{array}$ & $\mathrm{mg} / \mathrm{L} / 48 \mathrm{~h}$ & 98 \\
\hline $\begin{array}{l}\text { NOEC for invertebrates } \\
\text { (Daphnia magna, according to the } \\
\text { OECD Test Guideline 202) }\end{array}$ & $\mathrm{mg} / \mathrm{L}$ & 40 \\
\hline
\end{tabular}


allowed us to accurately trace the dynamics of aluminum compound transformation under the conditions of an active biotic model based on two main components of the lake biotope: water and lake sediments.

\subsection{Sampling and Analytical Methods}

A study of water parameters and bottom sediments was conducted from spring to autumn during both research years (2014-2015). Water samples were collected 4-5 times in the season using a Ruttner sampler. At the same time, the N-B water was collected using a pipe grabber without disturbing the sediment structure. Sediment sampling was performed using a Kajak-type sampler twice during each research season. At each sampling time, 1-2 independent undisrupted sediment cores were collected. Each core was then divided into 4 layers $(0-5,5-10,10-15$, and $15-20 \mathrm{~cm}$ below the bottom level) and packed in polyethylene containers. In the laboratory, bottom sediments were centrifuged (20 min at $3000 \mathrm{rpm}$ ) to obtain interstitial water. The solid fraction was immediately dried at room temperature, ground in an agate mortar, and sent for further analysis.

The monitoring parameters of the surface, near-bottom, and interstitial waters investigated in this paper included the aluminum content (Al), alkalinity (ALK), and acid/base level $(\mathrm{pH})$. ALK was analyzed according to the APHA standard method (APHA 2005). The total $\mathrm{Al}$ concentration was determined using the eriochrome cyanine $\mathrm{R}$ photometric technique. The dissolved Al concentration was determined with the same method after samples were filtered through $0.45-\mu \mathrm{m}$ glass-fiber filters. $\mathrm{pH}$ levels were measured in situ (surface and near-bottom water in mesocosms) or in the laboratory (interstitial water) using an Elmetron CX-401 pH meter. The aluminum concentration in the bottom sediments was analyzed according to Januszkiewicz (1978). The statistical analysis included comparative statistics, and the significance of the differences between the selected parameters in the matched pair system was analyzed. The normality of datasets was checked with a Shapiro-Wilk test, and in the case of a positive result, the data were subjected to a $T$ test; in the case of a negative result, the data were subjected to the Wilcoxon matched-pairs signed-rank test. All statistical analyses were conducted using the Statistica 12.0 software (StatSoft, Inc., Tulsa, OK, USA).

\section{Results and Discussion}

The phosphorus inactivation method, which was developed and implemented for the first time in the 1970s, remains controversial. Numerous review papers (Dunst et al. 1974; Cooke et al. 2005; Klapper 1991, 2003; Lossow and Gawrońska 2000; Łopata et al. 2020) have highlighted the advantages of this traditional reclamation approach, including a fast operation time, relatively low cost of treatment, flexibility in the arrangement of treatment steps, and, most importantly, the high certainty of phosphorus immobilization in lake environments. However, this last benefit can only be achieved if the procedure is performed properly. A key element in achieving the planned effects is implementing a quick and effective hydrolysis process for the phosphorus binding agent (most commonly aluminum or iron, Klapper 1991). Additionally, the ecological safety of the treated ecosystem must be maintained. The process of hydrolysis and the subsequent flocculation of the coagulant converts the dissolved form of the metal into the solid phase; thus, this approach is highly effective in binding the suspended particles in water. In addition, metal cations are cross-linked to hydroxide chains, which create amorphous floc structures (Fig. 1), and the toxic properties of hydrobionts are mitigated.

The proper implementation of coagulant applications in lakes is especially important for projects in which aluminum coagulants are used for the precipitation of phosphorus. The widely known toxic properties of aluminum when it interacts with hydrobionts (Poléo 1995; Graczyk 1992; Wauer et al. 2004) are associated with an extremely high environmental risk in the case of an incorrect restoration plan. Considering the amphoteric characteristics of aluminum and its naturally increasing solubility beyond the range of $\mathrm{pH} 5-9$, the greatest risk of the degradation of biological structures occurs in water bodies with low buffer capacities. The research performed in this work confirms these threats.

Figure 2 presents the dynamics of aluminum content changes during the 2-year experiments. Based on doses of PAC coagulant in the range of 0.5-2.0 times the theoretically required amount of $\mathrm{Al}$, a number of different scenarios were explored. The range of aluminum concentrations present in the water in each experimental basin varied over a very wide range of $<0.01$ to $16.5 \mathrm{mg} / \mathrm{L}$, and the dissolved fraction ranged from < 0.01 to $6.5 \mathrm{mg} / \mathrm{L}$. The highest fractions were observed in the two most dystrophic lakes: Zbiornik Zachodni and 


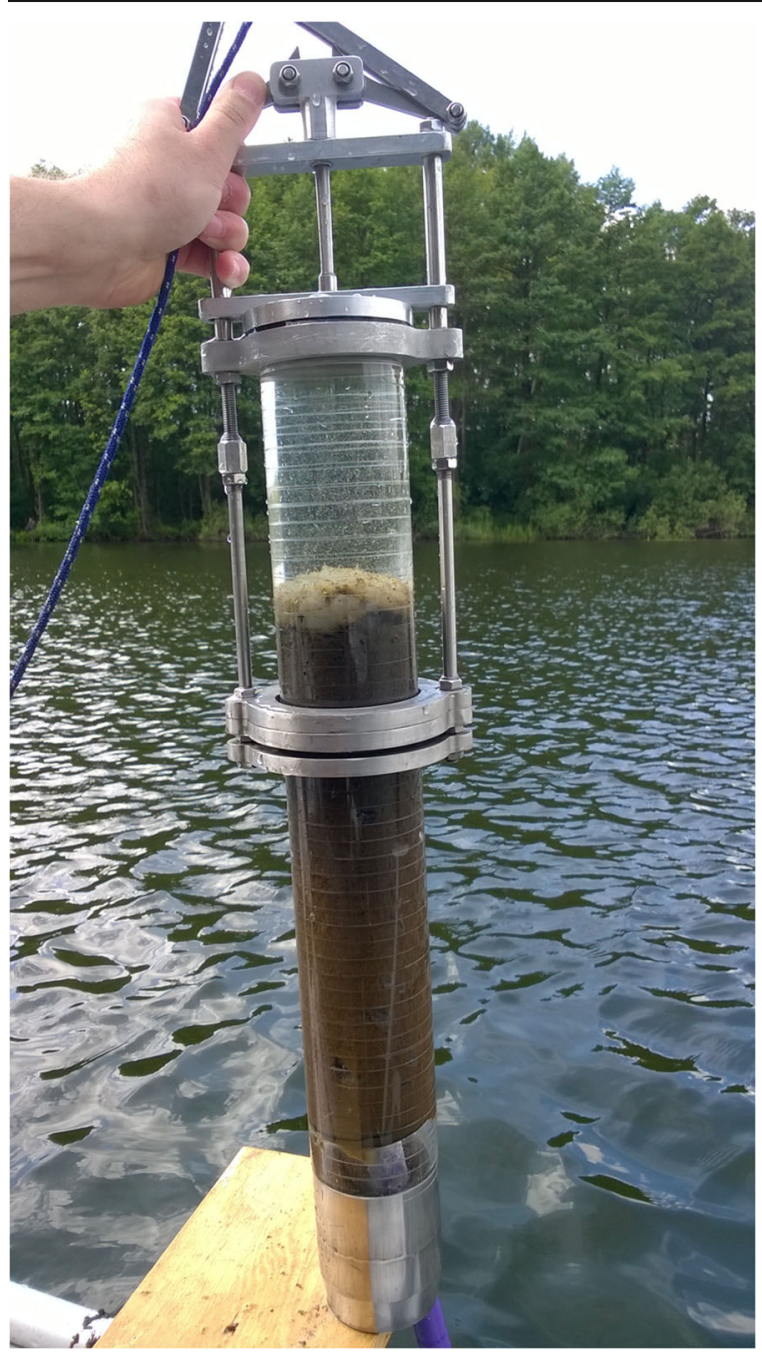

Fig. 1 Sampling procedure. An undisturbed core collected from mesocosms treated with a double dose of coagulant (Lake Podkówka). PAC flocs visible on the bottom surface (photo from M. Łopata)

Kluka Mała Lake; among the lakes studied, these lakes were characterized by natural slightly acidic $\mathrm{pH}$ values and very low alkalinity. Moreover, in these water bodies (especially Zbiornik Zachodni), persistent acidification during the entire vegetation season was observed in the first year of the experiment (for the scenario with a single application of the entire technical dose).

Under such conditions, the repeated application of the coagulant did not lead to the efficient precipitation of coagulant flocs. A comparison of the unit dose of aluminum to the concentration obtained within the mesocosms with the highest amounts of introduced coagulant showed that only $39.8 \%$ (ZZ) and $61.9 \%$
(KM) of polyaluminum chloride (on average) underwent effective sedimentation during the second research season. The water alkalinity in these water bodies, in connection with the initial $\mathrm{pH}<7.0$, was too small to compensate for the changes caused by the use of a strongly acidic preparation material. These results correspond well with those in previous reports by Klapper (2003), who reported limit-safe doses of aluminum sulfate at the level of $3 \mathrm{~g} \mathrm{Al} / \mathrm{m}^{3}$ for every $10 \mathrm{mg} / \mathrm{L}$ of $\mathrm{CaO}$ in terms of the water buffer capacity. The prehydrolyzed PAC coagulant is characterized by a less acidifying effect (Smoczyński et al. 2009) than that of classical aluminum sulfate.

The positive ecological effect of reclamation with polyaluminum chloride resulted in a satisfactory reduction in the level of eutrophication; however, an acceptable level of water pollution must be maintained in a lake with respect to aluminum compounds. Herman (2001) indicated that most often, a negative impact on bottom fauna can be observed when the level of inorganic aluminum reaches $0.1-0.3 \mathrm{mg} \mathrm{Al} / \mathrm{L}$. Cooke et al. (2005) and Wauer et al. (2004) specified that a safe level should not exceed $0.05 \mathrm{mg} \mathrm{Al} / \mathrm{L}$ in terms of the dissolved fraction. The experiments of Mácová et al. (2010) indicated that the acute toxicity values of PAX18 (common commercial PAC-type coagulant) found in tests of Danio rerio were 6-13 times higher than the concentration that is usually applied to waters $(5-10 \mathrm{mg} /$ $\mathrm{L}$ of $\mathrm{Al})$. Due to the potential long-term effect of coagulant flocs on the aqueous environment, $0.05 \mathrm{mg} \mathrm{Al} / \mathrm{L}$ seems to be an appropriate reference level for the dissolved form of aluminum.

With regard to this threshold, in experimental lake trials using the required standard dose of coagulant, an ecologically acceptable effect was obtained in three water bodies (Kluka Duża, Podkówka, and Redykajny, with values of $0.05 \pm 0.01,0.03 \pm 0.01$, and $0.02 \pm$ $0.01 \mathrm{mg} \mathrm{Al} / \mathrm{L}$, respectively). In lakes where the alkalinity exceeded $1 \mathrm{meq} / \mathrm{L}$ (Podkówka and Redykajny), doubled doses of coagulant (corresponding to a single application of the entire dose) theoretically did not threaten the hydrobionts (dissolved Al $0.05 \pm 0.04$ and $0.02 \pm 0.02 \mathrm{mg} / \mathrm{L}$, respectively), and the precipitation of flocs from the water column was $98.8-99.8 \%$ of the weight of the given coagulant. Additionally, in all three reservoirs, the lowest amount of coagulant (corresponding to $0.25 \%$ of the entire technically required dose) was less ecologically safe (dissolved Al KD $0.07 \pm$ 0.03 , POD $0.07 \pm 0.03$, and RED $0.08 \pm 0.05 \mathrm{mg} / \mathrm{L}$ ) 

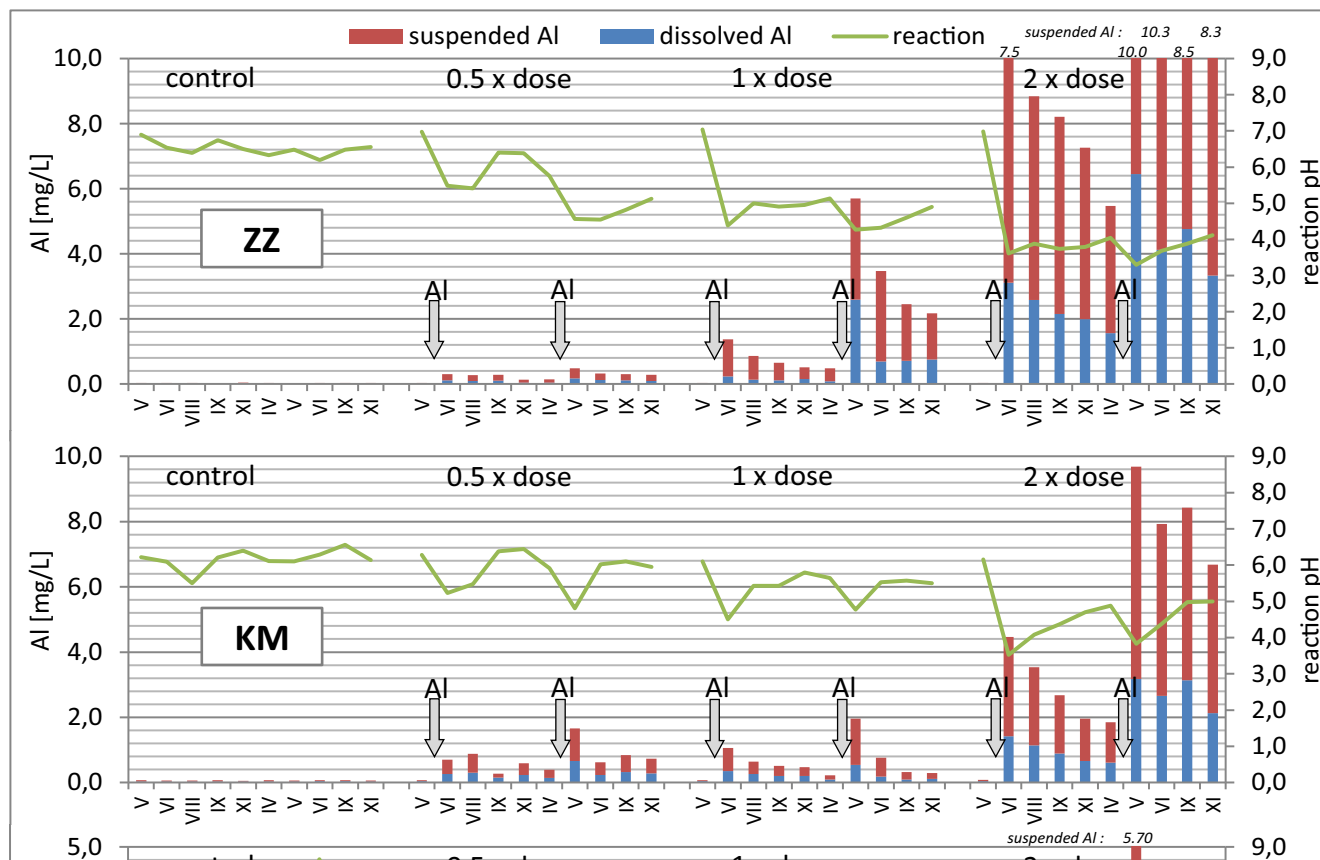

9,0

8,0

7,0

6,0 등

5,0 음
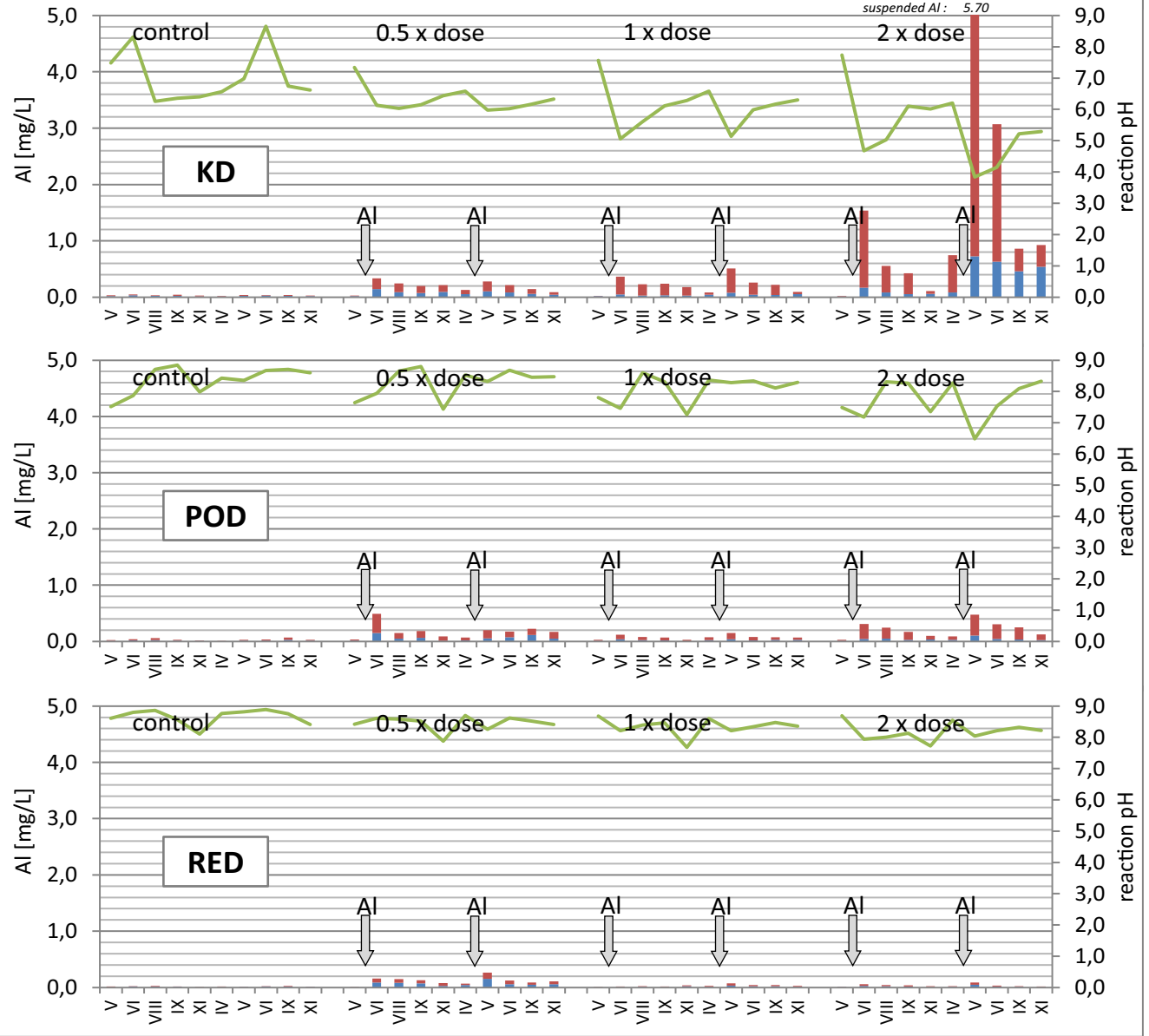

Fig. 2 Changes in the contents of the dissolved and suspended fractions of aluminum in the experimental systems. $X$-axis: months of sampling during the 2-year research cycle 

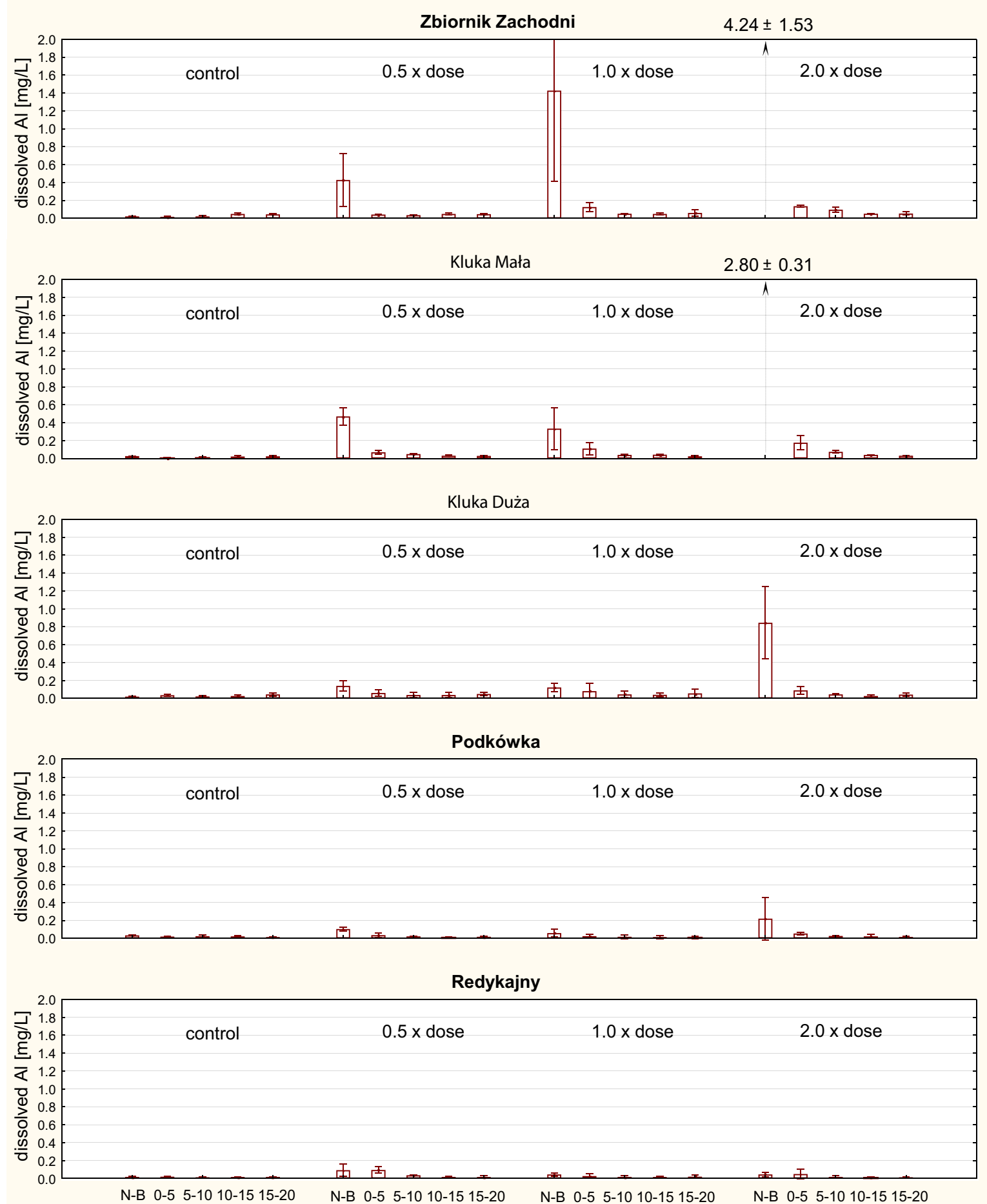

Fig. 3 Distribution of the dissolved aluminum concentration in the near-bottom (N-B) and interstitial waters (layers 0-5, 5-10, $10-15$, and $15-20 \mathrm{~cm}$ below the sediment table) in the researched mesocosms. Bars, mean; whiskers, SD. Data were collected in the 2015 growing season $(n=4)$ 
Table 2 Changes in the aluminum content (dry weight) of bottom sediments at the experimental sites

\begin{tabular}{|c|c|c|c|c|}
\hline \multirow[t]{2}{*}{ Layer $(\mathrm{cm})$} & \multicolumn{4}{|l|}{ Mesocosms } \\
\hline & $\begin{array}{l}\text { Control } \\
\mathrm{Al}_{2} \mathrm{O}_{3}(\% \text { d.w. })\end{array}$ & $\begin{array}{l}0.5 \times \text { dose } \\
\text { Comparativ }\end{array}$ & $\begin{array}{l}1.0 \times \text { dose } \\
\text { e average in }\end{array}$ & $\begin{array}{r}2.0 \times \text { dose } \\
\text { acrease }(\%)\end{array}$ \\
\hline \multicolumn{5}{|c|}{ Zbiornik Zachodni } \\
\hline $0-5$ & $0.73 \pm 0.05$ & $32.6^{*}$ & $51.9^{*}$ & $69.1 *$ \\
\hline $5-10$ & $0.76 \pm 0.05$ & 10.5 & $16.4^{*}$ & $19.7 *$ \\
\hline $10-15$ & $0.74 \pm 0.02$ & -3.7 & 7.8 & $9.8^{*}$ \\
\hline $15-20$ & $0.74 \pm 0.04$ & 1.9 & 5.3 & 1.3 \\
\hline \multicolumn{5}{|l|}{ Kluka Mała } \\
\hline $0-5$ & $1.31 \pm 0.11$ & $27.1 *$ & $42.0^{*}$ & $54.6 *$ \\
\hline $5-10$ & $1.51 \pm 0.06$ & 3.8 & 5.1 & 13.4 \\
\hline $10-15$ & $1.50 \pm 0.10$ & -2.8 & -0.2 & 4.8 \\
\hline $15-20$ & $1.43 \pm 0.14$ & -1.1 & -2.8 & 2.8 \\
\hline \multicolumn{5}{|c|}{ Kluka Duża } \\
\hline $0-5$ & $0.64 \pm 0.05$ & $28.1 *$ & $53.3 *$ & $95.7 *$ \\
\hline $5-10$ & $0.69 \pm 0.06$ & 11.5 & 18.1 & $32.7 *$ \\
\hline $10-15$ & $0.83 \pm 0.07$ & 0.9 & 3.3 & 6.3 \\
\hline $15-20$ & $0.75 \pm 0.03$ & 1.9 & -0.1 & -3.4 \\
\hline \multicolumn{5}{|l|}{ Podkówka } \\
\hline $0-5$ & $1.53 \pm 0.04$ & $15.5^{*}$ & $37.4^{*}$ & $52.0 *$ \\
\hline $5-10$ & $1.50 \pm 0.07$ & 4.5 & 6.2 & $17.5^{*}$ \\
\hline $10-15$ & $1.30 \pm 0.14$ & 1.0 & 4.0 & 1.3 \\
\hline $15-20$ & $1.15 \pm 0.08$ & 3.7 & 3.3 & 2.8 \\
\hline \multicolumn{5}{|l|}{ Redykajny } \\
\hline $0-5$ & $2.10 \pm 0.13$ & $12.4 *$ & $30.3 *$ & $63.0 *$ \\
\hline $5-10$ & $2.29 \pm 0.11$ & 6.7 & $10.2 *$ & 13.9 \\
\hline $10-15$ & $2.59 \pm 0.19$ & 1.2 & 2.3 & 6.7 \\
\hline $15-20$ & $3.00 \pm 0.22$ & -6.2 & -2.3 & -2.0 \\
\hline
\end{tabular}

*Statistically significant at $p=0.05$

than applying half the dose required in each year of reclamation (mesocosm "1.0 $\times$ dose"). These observations can be explained by the dynamics of the flocculation process. A small dose of coagulant uniformly introduced into the interior of a mesocosm was not conducive to initiating the phase of rapid floc growth. We observed similar dependences in relation to polyaluminum chloride in laboratory tests (Łopata et al. 2013). There is a high probability of reducing this effect at full scale due to coagulant-feeding boats moving along the designated routes and linearly distributing the preparation. An excellent flocculation rate was observed just after the boat application due to the variety of point concentrations of aluminum in the cloud of the coagulant suspension generated by the dosing system (author's field observations).

The phosphorus inactivation method consists of permanently leaving the components of the water purification preparation in situ. The coagulants fall to the bottom of the water reservoir, and chemical interactions are concentrated in the water-bottom sediment interphase area. The macroscopic form of the chemical sludge is initially clearly visible (Fig. 1), but over time, the sludge undergoes various transformations. In general, the consolidation of flocs to an increasingly compact form (aging of flocs) is observed. This effect may be due to the defragmentation of the chemical sludge layer, which is particularly evident in the case of a biologically active bottom (bioturbation). Due to the potential negative ecological effects of the mixing of coagulant flocs with native bottom sediment on benthos, the question related to identifying the future fate of these substances is important. There are few reports in the literature describing the extent of the effect of preparations on the environment of bottom sediments. According to studies by Lewandowski et al. (2003), flocs can easily penetrate to a depth a few dozen centimeters below the bottom of a reservoir. Our field observations from several lakes in Poland reclaimed with polyaluminum chloride in recent years (e.g., Lake Długie, Lake Wolsztyńskie, and Lake Klasztorne Górne) indicate that granules of chemical sludge are mainly located at depths of up to $10 \mathrm{~cm}$. In turn, fragments of aluminum sulfate from dose applications in Lake Starodworskie from 1994 to 1995 were found at depths of up to $20 \mathrm{~cm}$.

In the present research, the concentrations of aluminum in the bottom sediments were analyzed, and the corresponding synthetic results are given in Fig. 3 and Table 2.

In interphase waters, the contents of dissolved aluminum fractions corresponded to the amounts observed in the water column; in general, these contents were slightly (by 10-30\%) higher in N$\mathrm{B}$ water, which was likely caused by the slow formation of flocs as the concentration of aluminum increased in the bottom particles. The exception here was Lake Redykajny, in which the displayed a decrease in the aluminum concentration in N-B waters, with a value reaching < $0.1 \mathrm{mg} / \mathrm{L}$. Most likely, the reason for this phenomenon was the relatively low (close to neutral, and therefore more favorable for hydrolysis processes) $\mathrm{pH}$ level in the N-B region. 
Significantly lower concentrations of aluminum were observed in pore waters than in near-bottom waters. This result was observed in all the studied lakes and sediment layers in the experimental mesocosms. The consistent phenomenon in all the experimental mesocosms was the increase in the aluminum content in pore waters from that in the shallowest layers $(0-$ $5 \mathrm{~cm}$ ). The $0.1 \mathrm{mg} \mathrm{Al} / \mathrm{L}$ threshold was exceeded in Zbiornik Zachodni and Kluka Mała, which were the most dystrophic and low alkalinity waters studied. The other layers of bottom sediment in these lakes and all the cores collected from the other lakes were characterized by pore water levels of $<0.05 \mathrm{mg} \mathrm{Al} / \mathrm{L}$. No impact of coagulant application was associated with the high buffering properties of pore water (alkalinity usually 2 3 times higher than that of lake water, with a tendency to increase with core depth, as well as an increase in $\mathrm{pH}$ to values generally between 6.5 and 7.5 ). Such conditions favor the chemical stabilization of the prepared material and indicate that the previously precipitated material has a small chance of re-entering the dissolved phase. However, despite the high chemical stability of the bottom sediment, it is not possible to assume that aluminum is completely isolated in the coagulant granules of the bottom sediment environment. According to Berkowitz et al. (2006), coagulant flocs that undergo aging become susceptible to various transformations, including the loss of some sorption properties, such as that for phosphorus.

The analysis of the total aluminum content in the solid phase of the bottom sediments of individual layers (Table 2) provided detailed data on the spread of the coagulant mass in the sediment cores. During the period covered by the study, a statistically significant increase in the aluminum content was found only in layers up to $10 \mathrm{~cm}$ deep. The only exception was the mesocosm " $2.0 \times$ dose" (in Zbiornik Zachodni); notably, with the addition of the largest portion of the coagulant, an increase in the aluminum content was recorded in the sediments at a depth of $10-15 \mathrm{~cm}$. This observation was related to the ease of mechanical movement of the prepared material in the very loose sediment structure of this dystrophic reservoir. Considering the increase in the concentration of aluminum dissolved in pore waters in relation to the increase in the $\mathrm{Al}_{2} \mathrm{O}_{3}$ content in the dry mass of sediments, it should be noted that the migration process mainly involves the coagulant that has already precipitated in the form of flocs. This process is promoted by the loosely structured organic sediments and high biological activity of benthic organisms observed at all experimental sites. The diffusion of $\mathrm{Al}^{3+}$ ions deep into the sediment cores is a marginal process due to the rapid increase in the buffering properties of pore waters and the stabilization of the $\mathrm{pH}$, which was limited only to the surface layer of several centimeters of the bottom sediments.

\section{Conclusions}

The results of the 2-year in situ experiments performed in five soft-water lakes indicate the need for an individual approach when designing reclamation treatments in these types of ecosystems. The application of aluminum coagulants should be preceded by a detailed analysis of the environmental conditions of the water and bottom sediments. In this type of ecosystem, the danger of exceeding the natural buffer properties due to the use of inadequate doses of coagulant is very real.

In our experiments, we had the opportunity to observe various scenarios with different ecological consequences related to coagulant application. Among the lakes selected for testing, two reservoirs (Zbiornik Zachodni and Kluka Mała, which were the most dystrophic and alkaline of the waters studied at $0.4-0.7 \mathrm{meq} /$ L) were completely unfit for the safe use of polyaluminum chloride in eutrophication treatments. The level of $0.05 \mathrm{mg} \mathrm{Al} / \mathrm{L}$ was regularly exceeded after the application of coagulants, thus eliminating the possibility of reclamation with the tested coagulant in this type of water body. Two lakes with soft but moderately buffered water (1.5-2.5 meq/L; Podkówka and Redykajny) met the criteria for aluminum doses corresponding to the amount necessary for use at a full technical scale, even as an intensive one-stage project. This result reflects the high application potential for the use of aluminum coagulants for reclamation in lakes with similar physicochemical characteristics. Kluka Duża, the fifth reservoir, is a lake with both eutrophic and dystrophic features, low alkalinity $(0.5 \mathrm{meq} / \mathrm{L})$, and undigested water. This lake reacted much better to the experimental addition of polyaluminum chloride than did the more dystrophic lakes. The PAC applied in two stages with the total dose corresponding to the actual demand for the immobilization of phosphorus in the lake ecosystem did not result in unacceptable water pollution by aluminum. 
The results of our research indicate that for some degraded soft-water lakes, polyaluminum chloride treatment may be a safe method for de-eutrophication; however, it will be extremely difficult to achieve the desired effect in these lakes with reclamation based on phosphorus inactivation and acidic aluminum salts. Further research on improvements to this method should consider ways to limit the destabilization of the $\mathrm{pH}$ during aluminum application by testing new coagulants with lower acidities and/or selecting preparations that are safe for habitats by stabilizing the $\mathrm{pH}$ level.

Acknowledgments We would like to thank Anna Płachta, Konrad Rusiecki, Kamil Pstragowski, and Radosław Sternicki for the field work assistance.

Funding Information This study was supported by the Polish National Science Center, Project No. DEC-2012/05/B/ST10/ 02178. In addition, this project was financially supported by the Ministry of Science and Higher Education within the program entitled "Regional Initiative of Excellence" for the years 20192022; Project No. 010/RID/2018/19, with an amount of funding of 12,000,000 PLN.

Open Access This article is licensed under a Creative Commons Attribution 4.0 International License, which permits use, sharing, adaptation, distribution and reproduction in any medium or format, as long as you give appropriate credit to the original author(s) and the source, provide a link to the Creative Commons licence, and indicate if changes were made. The images or other third party material in this article are included in the article's Creative Commons licence, unless indicated otherwise in a credit line to the material. If material is not included in the article's Creative Commons licence and your intended use is not permitted by statutory regulation or exceeds the permitted use, you will need to obtain permission directly from the copyright holder. To view a copy of this licence, visit http://creativecommons.org/licenses/by/4.0/.

\section{References}

APHA (American Public Health Association). (2005). Standard methods for the examination of water and wastewater. $21 \mathrm{st}$ ed. Washington (DC).

Berkowitz, J., Anderson, M. A., \& Amrhein, C. (2006). Influence of aging on phosphorus sorption to alum floc in lake water. Water Research, 40, 911-916.

Brenntag Poland GmbH. (2015). Safety data sheet of polyaluminium chloride PAX 18. Brenntag Polska Sp. z. o.o., 1-7.

Chróst, R. (2017). Bioremediation of microbial contaminated and eutrophicated water reservoirs: myths and facts, for and against. Proceedings of the IX Scientific Conference "Hydromicro 2017: drobnoustroje - osiagnięcia $i$ wyzwania”, UWM, Olsztyn. (pp. 19).
Code of Good Agricultural Practice (in Polish). (2004). Ministry of Agriculture and Country Development, Ministry of Environment. Warsaw, 98.

Cooke, G. D., Welch, E. B., Peterson, S. A., \& Nichols, S. A. (2005). Restoration and management of lakes and reservoirs. Taylor \& Francis/CRC Press.

Davis, M. P., \& David, M. B. (2018). Nitrous oxide fluxes from agricultural streams in east-central Illinois. Water Air Soil Pollut, 229-354. https://doi.org/10.1007/s11270-018-40077.

Dunalska, J., Wiśniewski, G., \& Mientki, C. (2007). Assessment of multi-year (1956-2003) hypolimnetic withdrawal from Lake Kortowskie, Poland. Lake and Reservoir Management., 23, 377-387.

Dunst, R. C., Born, S. M., Uttomark, P. D., Smith, S. A., Nichols, S. A., Peterson, J. O., Knauer, D. R., Serns, S. L., Winter, D. R., \& Wirth, T. L. (1974). Survey of lake rehabilitation techniques and experiences. Department of Natural Resources, Madison Technical Bulletin, 75, 1-177.

Gawrońska, H., \& Lossow, K. (2008). Lake restorationlimitations and practical indications (in Polish). In: Jasser, I., Robak, S., \& Zdanowski, B. (eds.): Ochrona i rekultywacja wód Wielkich Jezior Mazurskich narzędziem rozwoju naukowego, gospodarczego, społecznego i kulturowego regionu. Inland Fishery Institute in Olsztyn, $39-51$.

Gołdyn, R. (2000). Shines and shadows of biomanipulation on the example of the Maltańskie Reservoir in Poznań (in Polish). Proceedings of the IX Scientific Conference "Ochrona $i$ rekultywacja jezior" Polish Association of Sanitary Engineers and Technicians, Przysiek, 145-153.

Graczyk, A. (1992). Aluminium-nowa trucizna $w$ środowisku (Aluminum: new poison the environment). Warsaw: OIKOS.

Grochowska, J., Augustyniak, R., Łopata, M., Parszuto, K., Tandyrak, R., \& Płachta, A. (2019). From saprotrophic to clear water status: the restoration path of a degraded urban lake. Water, Air, and Soil Pollution, 230, 94. https://doi. org/10.1007/s11270-019-4138-5.

Herrman, I. (2001). Aluminum is harmful to benthic invertebrates in acidified waters, but at what threshold(s)? Water, Air, and Soil Pollution, 130, 837-842.

Januszkiewicz, T. (1978). Studia nad metodyką analizy chemicznej składu współczesnych osadów dennych jezior. Zeszyty Naukowe Akademii Rolniczo-Technicznej w Olsztynie, Wydziat Ochrony Wód i Rybactwa Śródlądowego, 8, 3-30.

Jeppesen, E., Søndergaard, M., Jensen, J. P., Havens, K. E., Anneville, O., Carvalho, L., Coveney, M. F., Deneke, R., Dokulil, M. T., \& Foy, B. (2005). Lake responses to reduced nutrient loading - an analysis of contemporary long-term data from 35 case studies. Freshwater Biology, 50, 17471771.

Jeppesen, E., Søndergaard, M., Meerhoff, M., Lauridsen, T. L., \& Jensen, J. P. (2007). Shallow lake restoration by nutrient loading reduction-some recent findings and challenges ahead. Hydrobiologia, 584, 239-252.

Jeppesen, E., Søndergaard, M., Lauridsen, T. L., Davidson, T. A., Liu, Z., Mazzeo, N., Trochine, C., Özkan, K., Jensen, H. S., Trolle, D., Starling, F., Lazzarro, X., Johansson, L. S., Hansen, R. B., Liboriussen, L., Larsen, S. E., Landkildehus, F., Egemose, S., \& Meerhoff, M. (2012). Biomanipulation as 
a restoration tool to combat eutrophication: recent advances and future challenges. Advances in Ecological Research, 47, 411-488. https://doi.org/10.1016/B978-0-12-3983152.00006-5.

Kajak, Z. (2001). Hydrobiology —limnology. Inland water ecosystems (in Polish). Warsaw: PWN.

Klapper, H. (1991). Control of eutrophication in inland waters. New York: Ellis Hornwood.

Klapper, H. (2003). Technologies for lake restoration. Journal of Limnology, 62(1), 73-90.

Lewandowski, J., Schauser, I., \& Hupfer, M. (2003). Long term effects of phosphorus precipitations with alum in hypereutrophic Lake Süsser See (Germany). Water Research, 37, 3194-3204.

Łopata, M., Wiśniewski, G., \& Brzozowska, R. (2013). Aluminum treatment of low alkaline lake waters buffered with calcium carbonate-laboratory investigations. Global Journal on Advances Pure and Applied Sciences, 1, 704709.

Łopata, M., Wiśniewski, G., Parszuto, K., \& Dunalska, J. A. (2016a). From restoration to revitalization: How to recover recreational values of urban lakes. A case study of Lake Domowe Duże in Szczytno. Polish Journal of Natural Sciences, 31(3), 471-483.

Łopata, M., Wiśniewski, G., \& Augustyniak, R. (2016b) Changes of the organic matter content in the water of lakes with low alkalinity occurring under the influence of the use aluminum salts. Proceedings of 16-th International Multidisciplinary Scientific GeoConference SGEM, 129-136. https://doi. org/10.5593/SGEM2016/B31/S12.018.

Łopata, M., Augustyniak, R., Grochowska, J. K., Parszuto, K., \& Tandyrak R. (2020). Selected aspects of lake restorations in Poland. In: Korzeniewska, E., \& Harnisz, M. (eds): Polish river basins and lakes - part II: the handbook of environmental chemistry 87. Springer International Publishing AG, pp. 327-352. https://doi.org/10.1007/978-3-030-12139-6_15.

Lossow, K. (1998). Protection and reclamation of lakes. Theory and practice (in Polish). Idee Ekologiczne, 13, 55-70.

Lossow, K., \& Gawrońska, H. (2000). Lakes - restoration-review of methods (in Polish). Przeglad Komunalny, 9(108), 91-106.

Mácová, S., Plhalová, L., Široká, Z., Doleželová, P., Pištěková, V., \& Svobodová, Z. (2010). Acute toxicity of the preparation PAX-18 for juvenile and embryonic stages of zebrafish
(Danio rerio). Acta Veterinaria, 79, 587-592. https://doi. org/10.2754/avb201079040587.

OECD. (1982). Eutrophication of waters-monitoring, assessment and control (p. 154). Paris: The Organisation for Economic Cooperation and Development (OECD).

Olszewski, P. (1961). Versuch einer Ableitung des hypolimnischen Wassers an einem See. Ergebnisse des ersten Versuchsjahres. Proceedings of International Limnology Association, 18, 1792-1797.

Poléo, A. B. S. (1995). Aluminium polymerization - a mechanism of acute toxicity of aqueous aluminium to fish. Aquatic Toxicology, 31, 347-356.

Ripl, W. (1986). Lake restoration methods developed and used in Sweden. Restoration of lakes and inland water. EPA, 440(5), 81-100.

Rydin, E., \& Welch, E. B. (1998). Aluminum dose required to inactivate phosphate in lake sediments. Water Research, 32(10), 2969-2976.

Shapiro, J., \& Wright, D. I. (1984). Lake restoration by biomanipulation. Round Lake, Minnesota - the first two years. Freshwat Biol, 14, 371-383.

Siwek, H., Włodarczyk, M., \& Czerniawski, R. (2018). Trophic state and oxygen conditions of waters aerated with pulverising aerator: the results from seven lakes in Poland. Water, 10(219), 2-11.

Smoczyński, L., Dłużyńska, K., Pierożyński, B., Wardzyńska, R., Załęska-Chróst, B., \& Zaborowska-Piworowicz, A. (2009). Mechanism of P-PO4 removal from chemically treated wastewater. Ecological Chemistry and Engineering, 16(12), 135-149.

Wauer, G., Heckemann, H. J., \& Koschel, R. (2004). Analysis of toxic aluminium species in natural waters. Microchimica Acta, 146, 149-154.

Wiśniewski, R., Ślusarczyk, J., Kaliszewski, T., Szulczewski, A., \& Nowacki, P. (2010). "Proteus", a new device for application of coagulants directly to sediment during its controlled resuspension. Verhandlungen des Internationalen Verein Limnologie, 30(9), 1421-1424.

Publisher's Note Springer Nature remains neutral with regard to jurisdictional claims in published maps and institutional affiliations. 